during which time I have vaccinated nearly 800 children. In each case, by the direction of the National Vaccine Board, four punctures are made in one arm of the child, and to vaccinate four children I have never found it necessary to charge the lancet more than once. To practitioners who, like myself, vaccinate large numbers in the shortest possible time, this little instrument will be a great boon, as well as a great saving in lymph.

The maker, Mr. Matthews, of Portugal-street, has taken considerable pains to follow out my instructions, and has produced it in sereral neat and portable forms to suit the requirements of the practitioner.

Birmingham, Oct. 1856.

\section{RUPTURE OF THE LIVER. OPERATION AND CURE.}

Br W. F. M'MILLAN, M.D., Friockheim.

THe following case possesses so many points of practical interest, that I am induced to bring it under the nolice of the profession; and that the reacler may have the ringle case before him, I subjoin the report sent hoxe to Scolland with the patien fiom the surgeon who atter Jed him :-

"Wra. B-, aged twenty, was kicked by a horse on the 20 th of ipril iast, orer the region of the liver, causiag a con siderable smount of infammation, symptonatic with fever and jaundice, the fever and jaundice subsi.1ing about bhe screnteenth day. As a sequel to this, ascites set in, and has been very

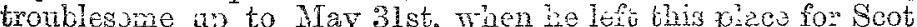
1end. Treatment curing the infommonory stage- Antinouals, a perients with mercury local bleeding, ponltires sud fomenta tions. Calomel and opium have bees purhed, so as slightly to affect the month. During the dropsical synotoms, Priction, with mercuria ointinent over the region of the liver, with diuretics, first of potass with spirio of nitroas ether, then sulwhate of magnesia ial the morning, wita alierative doses of blue pill

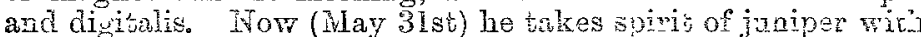
digitalis, and mercurial ointment with ionine and powdered digitalis ruobed over the whole region of the abdomen twice a day. I hare now recommended a change of air to his nasive country."

I was called to take charge of the case on the $2 a 1$ of June, the patient having arrived from Englard the previous evening. I found the abdumen greatly enlarged, about the size of a woman at tive finl term of utero-gestation; it felt hard, and unlike any case of ascites I had ever seen. I applied hot fomentations to sootie tille imitability caused by the enlargement of the abdomen, and gave anodynes to allay the systemic excitement resulting from so long a journey having been undergone in the patient's debilitated condition.

June 3rd. - Has slept little, continually crying ont, " $\mathrm{Oh}$, my belly!"- Twelve o'clock noon: A consultation on the case with Dr. Guthrie, senior, of Brechin, when, after a careful examination, we came to the conclusion that it was not ascites, as our Erglish friend had concluded, but that the enlargement was the result of effusion consequent on rupture of the liver, which was greatly enlarged, and gave great pain on being pressed. The bowels we found pushed into the left iliac region and the whole abdominal cavity occupied with fluid. Such being the opinion arrived at, to operate was clearly our duty, accordingly it was agreed that we should operate next day. Hot fomentations were continued; an aperient and an anodyne were given in the evening.

4th. - There were present Dr. Guthrie, sen., Dr. J. Guthrie, jun., and myself, when, having bandaged the abdomen as in the operation for ovarian dropsy, and placed the patient in the lithotomy position, Dr. Guthrie, sen., made an incision about an inch below the umbilicus, and introduced a trocar and canula. We drew off 324 fluid ounces of a grumous liquid, coinposed of blood, bile, \&c., which had a most ofiensive smell. Pieces of adhesive plaster were then strapped over the wound, and the whole abdomen very firmly bandaged. A sedative mixture was then given, and during the evening our patient had some sleep, and on awakening he partook of a little food.

5th.-Feels more comfortable this morning, and took some breakfast. Complained of some griping pains in the abdomen, for which an anodyne mixture was given.

I omit giving here the daily state I found him in, as it is of little moment; but he continued gradually to improve and gather strength till June 17 th, when he went out with me, and took a walk for nearly a quarter of a mile; and on the 18th he went alone to the other end of the village. About a week afterwards I recommended a short ride on horseback. He smiled when I proposed it; but on my offering him my horse, he mounted, and rode fully a mile, trotting some part of the way.

Sept. 4th. - From the 5th ultimo there has been gradual improvement, and now he is fally convalescent, being engaged in harvest operations in the field with his father.

\section{ANALYSIS OF THE}

WATER OF BEN RHYDDING, NEAR OTLEY, YOPKSHIPE.

BY SHERIDAN MUSPRATT, M.D., F.R.S. ED., PRINCIPAX OI THE LTERPOOL COLLEGE OF CHEMISTRY.

IT is a remarkable fact that no analysis of this water has hitherto been published. Ben Rhydding is at an elevation of 500 feet above the level of the sea. The soil is arenaceous, and the springs here are amongst the finest in Great Britain. From its situation mid way between the vast upland moors, and the sweet bunks of the placid Whare, Ben Phydding affords not only a favourable position from which to admire the varied scenery around, but one from which, by a walk requiring little time or exertion, the valetudinarion may enjoy what he desires, an agreeable chenge of temporature. As a matter of course, it is everything combined at such a place that produres the beneficial results. The wator flows from the principal fountain, which is called the "Shrine," at the rate of about three gallons per wimete. It has a temperature of $42^{\circ}$, and is exceedingly refreshing and cooling to the palate. Althongh it contains a litste more fixed air than the Malvern water, which I analyzed last Jear, still, being rather colder, it seems to exer's a more invigorating effect upon the partaker. Annexed are the regults of the solid constituents in a gallon of the water. The composition appears to me rather a singular one as compired with tha of other waters of a salubrious cha racter throughout the kingdom. The specific gravity of the water is 1.001207 .

\begin{tabular}{|c|c|c|c|c|}
\hline & & Grail & in in & \\
\hline Carbonate of line & & & & \\
\hline Carbonate of magnesia & $\cdots$ & $\cdots$ & $\cdots$ & Were traces \\
\hline Chloride of solium & & $\cdots$ & $=\ldots$ & $0 \cdot 914$ \\
\hline Uhloride oi magnesium & $\cdots$ & $\ldots$ & $\ldots$ & Trace \\
\hline Sulphate of lime... ... & $\ldots$ & $\ldots$ & $\ldots$ & $2 \cdot 295$ \\
\hline Sulphate of soda... & $\ldots$ & $\ldots$ & $\ldots$ & $0 \cdot 511$ \\
\hline Silicate of Potassa & $\ldots$ & $\ldots$ & $\ldots$ & $1 \cdot 315$ \\
\hline & & & & \\
\hline
\end{tabular}

On looring at the figures, it appears that the water almost entirely consists of a silicate and a calcareous sulphate. October, 1860 .

\section{ALARMING EFFECIS PRODUCED BY AN OVERDOSE OF OPIUM IN A CHILD. RECOVERY.}

\section{By HUNTER FINLAY, M.D., Bothwell.}

AвоUт eight o'clock in the evening of the 28th of August I was called to see a child who was stated to have been poisoned with opium. As the place was several miles distant from my house I did not arrive till nearly ten o'clock, when I found the patient, a little boy aged eighteen months, lying in bed in a state of stupor; the pupils firmly contracted; the pulse quick and irregular; the breathing slightly stertorous. On inquiry, I ascertained that he had received the opium about ten o'clock in the forenoon; that by about noon he was observed to become drowsy, and irritable when his mother tried to awake him. About one P.M. the stupor deepened, and he continued asleep till I saw him. The mother stated that the child had for several days been troubled with diarrhoea, and that the opium had been administered for its cure. I was shown several pills, which seemed to be pieces of solid opium-as if they had been broken from a cake of crude opium, and rolled into irregular 